\title{
The Influence Of Mary Bentham On John Stuart Mill ${ }^{1}$ CATHERINE PEASE-WATKIN \\ Bentham Project, University College London \\ c.pease-watkin@ucl.ac.uk
}

The influence which Jeremy Bentham had on the young John Stuart Mill arose primarily from the close friendship between Bentham and John's father James Mill, and is well-known and well-documented. ${ }^{2}$ From 1810 until 1831 the Mill family were close neighbours of Bentham, and lived in properties belonging to him. The Mills also spent several summers at Bentham's country residence Ford Abbey in Devon, and in his Autobiography John Stuart Mill acknowledges the impression which those visits made on him. ${ }^{3}$ Mill displayed his exceptional intelligence from an early age, and clearly bore similarities to the young Bentham, who had also been a child prodigy, and also driven to excel from a very young age by an ambitious father. The relationship between Bentham and his disciple James Mill was the main cause of Bentham's involvement with John Stuart Mill, but perhaps the similarities between them provided an additional contributing factor to Bentham's interest in the boy.

Packe, in his 1954 biography, lists the influences on Mill thus: 'the two Benthams, Ricardo, Place - all remarkable men, able and active, old enough to

\footnotetext{
${ }^{1}$ A version of this paper was given at the John Stuart Mill Bicentennial Conference, UCL, 5 April 2006. I would like to thank my colleagues Catherine Fuller, Deborah McVea and Philip Schofield for their comments on earlier drafts.

${ }^{2}$ See, for example, the jocular letter from Bentham to Mill of July 1812: 'if you will appoint me Guardian to Mr John Stewart Mill, I will ... do what soever may seem most necessary and proper, for teaching him to make all proper distinctions, such as between the Devil and the Holy Ghost, and how to make Codes and Encyclopaedias..'. Mill's reply is more serious in tone: 'if I were to die any time before this poor boy is a man, one of the things that would pinch me most sorely, would be, the being obliged to leave his mind unmade to the degree of excellence, of which I hope to make it. ... the only prospect which would lessen that pain, would be the leaving him in your hands. I therefore take your offer quite seriously ... and then we may perhaps leave him a successor worthy of both of us'. See The Correspondence of Jeremy Bentham, vol. viii, ed. S. Conway, Oxford, 1988 (CW), pp. 253, 255.

${ }^{3}$ See Autobiography and Literary Essays, ed. J. M. Robson and J. Stillinger, Toronto, 1981 (vol. i of The Collected Works of John Stuart Mill, henceforward CWJSM) p. 57: 'This sojourn was, I think, an important circumstance in my education. Nothing contributes more to nourish elevation of sentiments in a people, than the large and free character of their habitations. The middle-age architecture, the baronial hall, and the spacious and lofty rooms, of this fine old place, so unlike the mean and cramped externals of English middle class life, gave the sentiment of a larger and freer existence, and were to me a sort of poetic cultivation, aided also by the character of the grounds in which the Abbey stood; which were riant and secluded, umbrageous, and full of the sound of falling waters'.
} 
stretch a young boy's intellect'. Then he emphasises: 'No women'. ${ }^{4}$ The second of 'the two Benthams' mentioned is Jeremy's brother Sir Samuel Bentham (17571831), naval architect and engineer. At the age of fourteen, Mill spent almost a year with Samuel Bentham and his family, who were living in the south of France. Presumably it is because of this visit that Packe identifies Samuel Bentham as one of the 'remarkable men' who left their mark on Mill. However, it is my view that Packe has unfairly excluded Samuel's wife Mary Sophia Bentham (née Fordyce) from his list of influences, and has failed to give her credit for her contribution to the young Mill's development and achievements during his stay in France.

Mary Sophia Fordyce was born in 1765, the elder daughter of George Fordyce, doctor and scientist, whom Jeremy and Samuel Bentham had known from a young age. Jeremy Bentham attended Dr Fordyce's lectures on chemistry as a very young man, and in a will he wrote when he was 21 , he stipulated that, should there be any advance in medical science to be gained from the examination of his corpse, his body should be delivered to Dr Fordyce for that purpose. ${ }^{5}$ At a time when educational opportunities for women were extremely limited, Mary Fordyce was clearly a clever and capable woman: according to her son, the botanist George Bentham, she 'had from an early age been accustomed to take a part in her father's writings' ${ }^{6}$

A letter from Samuel Bentham to Mary, written the year before they married, makes it clear that she shared Samuel's interest in science and mechanics. It is evident from the letter that she has been engaged in a scientific experiment to do with the exhaustion of air for mechanical purposes. Samuel concludes: 'In the mean time you may make Upsal give you an account of Barr's progress with his hammering machine. I fear he will break a few glass cilinders', not perhaps an obvious remark to find in a letter of courtship. ${ }^{7}$ Jeremy Bentham, in the early

\footnotetext{
${ }^{4}$ M. S. J. Packe, The Life of John Stuart Mill, London, 1954, p. 48.

${ }^{5}$ See The Correspondence of Jeremy Bentham, vol. i., ed. T. L. S. Sprigge, London, 1968 (The Collected Works of Jeremy Bentham, hereafter $C W)$, p. 136 \& n.

${ }^{6}$ George Bentham, Autobiography 1800-1834, ed. Marion Filipiuk, Toronto, 1997, p. 4.

${ }^{7}$ Letter of 9 February 1795, Royal College of Surgeons, Hunter-Baillie collection. Richard Upsal was a seaman who had enlisted under Samuel Bentham in Russia, and was later (between 1797 and 1804) to hold clerkships at the Admiralty under him. Evidently during the 1790s Upsal was frequently used as a messenger by both Benthams. James Burr was to become a draftsman in the naval works department 1796-1805. According to Mary Bentham, Burr (or Barr as she called him) was chosen by Sir Samuel 'not on account of any neatness or proficiency in drawing' but because he had served as an apprentice in a dockyard and 'had been for several years accustomed to working machinery of Bentham's invention', as this letter demonstrates. See M. S. Bentham, The Life of
} 
years of their acquaintance, also used Mary Fordyce as a 'research assistant', as several manuscripts in the UCL collection indicate, which is a tribute to her intellectual capabilities. One letter survives, which Mary wrote to Samuel in 1794: it begins with a reference to information which she had been collecting for Jeremy - 'Tell your brother that the extinct peerages are made out as far as was possible' - and concludes with some teasing remarks about a gift of walnuts'. ${ }^{8}$ Other manuscripts contain material about bankers and banking which she had collected for Jeremy Bentham ${ }^{9}$ The marriage of Samuel Bentham and Mary Fordyce, which took place in October 1796, was evidently one of scientific minds. Between 1797 and 1804 the couple had three daughters and two sons of their own, and for at least some of the time they also looked after one or more of Samuel's illegitimate children.

Now let us consider Mary Bentham's qualities as a teacher. There is a reference from as early as 1794 to her teaching one of Jeremy Bentham's amanuenses to write and count. ${ }^{10}$ An undated scrap of manuscript in her hand gives us some idea of her ingenuity when teaching children. She is describing how easy it is to demonstrate mechanical principles by using everyday household items, suggesting that wood, bread or paper can all be used to make, and demonstrate the properties of, cubes. Using a scale, either a small medicine scale, or one 'made of a match and two half wallnut shells', the relative weights of cubes of different materials can be assessed. She concludes that

the knowledge acquired of cubical contents is immediately found by very young children to turn to good account, a cubical lump of sugar will be chosen in preference to the broadspreading thin slice ${ }^{11}$

which shows her empathy with children and the way they think.

Between 1805 and 1807, the Samuel Benthams lived in Russia, and of this period Filipiuk remarks: 'Lady Bentham was able to devote herself completely to supervising [the children's] education, and she was a remarkable educator'. ${ }^{12}$

\footnotetext{
Brigadier-General Sir Samuel Bentham, London, 1862, p. 118.

${ }^{8}$ UC clxvi. 477.

${ }^{9}$ UC cxv. 33-9.

${ }^{10}$ See Correspondence $(C W)$, v. p. $103 \& \mathrm{n}$.

${ }^{11}$ UC clxv. 45.

${ }^{12}$ G. Bentham, Autobiography, p. xxi.
} 
George Bentham tells us in his Autobiography that he and his siblings had all learned to read and write very early, and what is noticeable from the Bentham correspondence from the time of the stay in Russia is that the children were studying more than just academic subjects. ${ }^{13}$ All the children were picking up Russian and French from their Russian governess; they also began learning botany and horticulture (particular interests of Mary Bentham's) and other practical subjects such as carpentry. Thus the interests of both parents were channelled into the children. The girls had begun dressmaking before leaving London for Russia, and while in Russia both the brothers and the sisters began studying music. A letter written later alludes to the wide range of subjects which the Bentham children were studying: music, German, French, Latin, chemistry, history, maths and geometry. ${ }^{14}$ Mary Bentham's sensitivity to the needs of individual children is demonstrated by a remark she made to Jeremy Bentham: explaining that she has allowed her daughter Clara to have a pair of canaries as pets, she says, 'We used you may recollect, to forbid birds and indoor pets of all kinds, but how impossible it is to lay down rules for education which will suit with all', an educational precept which is still perfectly valid today. ${ }^{15}$

In 1814 Samuel and Mary Bentham and their children, aged between ten and sixteen, moved to France, where they were to live for the next thirteen years. While it is true that the actual mechanics (as it were) of the children's lessons were the responsibility of masters and governesses, both parents were actively involved in determining what subjects the children should study, and in finding suitable tutors. In the autumn of 1814 Mary Bentham describes Saumur as 'of all the places I have seen the most desirable for a family of young children to be brought to for education', ${ }^{16}$ and Samuel Bentham too writes that he has been 'looking out for Masters'. ${ }^{17}$ Although in later years George was to express regret that he and his siblings had never been sent to school ${ }^{18}$ it is clear that both parents took the duty of educating their family very seriously. George, the sole surviving son after the death of his brother Samuel in 1816, took up Greek with a local scholar, began Hebrew at

\footnotetext{
${ }^{13}$ Ibid., p. 4.

${ }^{14}$ Etienne Dumont to Samuel Romilly, 9 October 1810, Bibliothêque publique et universitaire, Geneva, Dumont MSS 17. f. 234.

${ }^{15}$ Correspondence $(C W)$, ix. p. 295.

${ }^{16}$ Correspondence $(C W)$, viii. p. 427.

${ }^{17}$ Correspondence $(C W)$, ix. p. 203.

${ }^{18}$ G. Bentham, Autobiography, p. 8.
} 
the university, and continued with his study of Spanish and German. ${ }^{19}$ All the Bentham children, during their time in France, continued with the varied curriculum of their earlier years, which included music and dancing.

So this was the household of young people, with a daily regime of academic, artistic and outdoor pursuits, that welcomed John Stuart Mill in June 1820. At fourteen, he was a couple of years younger than the youngest Bentham daughter Sarah, but in intellectual achievement he was very advanced. At the time of the exchange of letters between Jeremy Bentham and James Mill in 1812, John Stuart Mill was occupied in 'recapitulating the 1st and 2d. volumes' of a fourvolume work on Roman History - quite an achievement for a six year old boy. ${ }^{20} \mathrm{~A}$ letter he wrote to Samuel Bentham in July 1819, in which Mill refers to the latter's 'inquiries' about his studies, gives an outline of his education to date, and it is an impressive account. He has studied a wide range of the classical authors, many works of mathematics, science, logic, the beginnings of political economy, and more. $^{21}$ The intention behind his visit to France was primarily that he should improve his French - to experience what Robson describes as 'a linguistic and cultural immersion', and from the Journal which he kept for the first six months or so of his stay with the Benthams, we get a very detailed picture of what he studied while in France. ${ }^{22}$ If we compare the works studied by John Stuart Mill before he went to France with those he read while he was there, it is noticeable how little overlap there is, and presumably one reason for Samuel Bentham's request for an account of the boy's studies so far was precisely to ensure that he should not cover the same ground again.

The main reason for the visit to France, as noted above, was the improvement of Mill's knowledge of French. Although Mill's Journal records his continuing reading in Greek, Latin and the sciences, he was mainly reading French: fables, comedies, and tragedies, and he got through them at an astonishing rate. He was also studying the history, the geography, and the politics of the country. After only a fortnight with the Benthams, Mill was able to converse fluently in French. ${ }^{23}$

To what extent, then, was Mill guided by Mary Bentham in his programme

\footnotetext{
${ }^{19}$ Correspondence $(C W)$, ix. 291-92.

${ }^{20}$ See n. 2 above.

${ }^{21}$ The Earlier Letters of John Stuart Mill 1812-1848 (CWJSM), ed. F. E. Mineka, Toronto, 1963, pp. 610.

${ }^{22}$ Journals and Debating Speeches (CWJSM) ed. J. M. Robson, Toronto, 1988, p. xii.

${ }^{23}$ Ibid., p. xv.
} 
of study? The Journal provides some answers to this question. For example, Mill notes that he is reading French plays 'chiefly by the advice of Mr George and of Lady Bentham, who say that dialogues are better to be read, on account of their giving the $1^{\text {st }}$ and $2^{\text {nd }}$ person of the verbs, and for many other reasons'. ${ }^{24}$ She advised him to read 'such parts as she should point out of the Code Napoleon, presumably both for its language and for its content. ${ }^{25}$ Elsewhere Mill records that Lady Bentham has advised him to learn fables by heart, in order to improve his pronunciation by reading them aloud, and also because the clarity of the language of fables, Lafontaine's in particular, is such that they provide good examples both of grammar and of the meaning of words. ${ }^{26}$ So Mary Bentham is not only telling him what to read, but also explaining why he should be reading it.

Alongside French, Mill continued to study the classical, mathematical and scientific subjects which formed the backbone of his previous curriculum. It is perhaps a further tribute to Mary Bentham that her daughters, as well as her son, seem to be well-educated: at one point the eldest Bentham daughter, Mary Louisa, who was eight months pregnant at the time, showed Mill a book on Geometry which he later considered to 'contain the best system of Geometry [he had] ever known of', and she also lent Mill her 'set of portable shelves', presumably thinking that, in her condition, she wouldn't be needing them for a while. ${ }^{27}$ Mary Bentham set her pupil assignments on a variety of subjects: she suggested that he write a dialogue on the subject of whether large estates and establishments, or small ones, 'are the most conducive to the general happiness', perhaps one of Mill's first forays into utilitarianism. On another occasion, she advised him to write a treatise on the definition of political economy. ${ }^{28}$

Although Mill was an assiduous scholar, willing and able to study for long hours on end, the somewhat chaotic Bentham household sometimes forced him to slow down: on occasion he would find the library locked and therefore be unable to work; ${ }^{29}$ and some mornings he took to sleeping late, either because of 'not knowing the hour' or because of having 'nothing to do'. ${ }^{30}$ Thus the more leisurely pace of life in France began to have an effect.

In addition to his academic studies, Mary Bentham made sure that Mill was

\footnotetext{
${ }^{24}$ Entry for 13 June 1820; ibid., p. 22.

${ }^{25}$ Ibid.

${ }^{26}$ Ibid., p. 45.

${ }^{27}$ Ibid., pp. 26, 33.

${ }^{28}$ Ibid., p. 54.

${ }^{29}$ Ibid., p. 22.

${ }^{30}$ Ibid., pp. 26, 31.
} 
exposed to a wide variety of what would now be called extra-curricular activities. As he notes in his Journal: 'Lady B. wishes besides to find me various other kinds of masters, so that, with my Latin, Greek, Mathematics, etc. you see I shall not lead an idle life here'. ${ }^{31}$ By mid-July 1820 he was taking lessons in dancing, music, riding and fencing, and in addition Lady Bentham advised him to watch the dancing lessons taken by the girls as 'she considers it of great use that I should see dancing'. She is tactfully concerned that James Mill should not be worried about the expense of so many masters: on her advice, John sends his father detailed accounts of the costs of all the lessons, to reassure him that they are remarkably good value ${ }^{32}$ indeed, the cheapness of tuition had been one of the main reasons for the Bentham family's decision to settle in France. ${ }^{33}$

Besides lessons, there were outings to the theatre and to local feast days, beginning the very day after his arrival. ${ }^{34}$ During his stay in France, and particularly in the summer, Mill spent a lot of time on outdoor pursuits, such as walking, swimming in the river, accompanying George on 'botanising' expeditions, and going out in the carriage. All the young Benthams were used to driving, and indeed Mill says of Sarah Bentham, 'she drives very well, and, by her own account, is very fond of driving'. ${ }^{35}$ However, trips in the carriage with the Benthams do seem to have been rather risky. Mill records in his Journal: 'the unfortunate charaban lost a fore wheel, but Mr. G. [i.e. George] with some difficulty, restored it to its place. The number of accidents which we are doomed to encounter in our poor vehicle seems to be unlimited; we can already count 1 overturn, 1 breaking down, and twice the loss of a wheel'. ${ }^{36}$

In August 1820 the family left their accommodation in Toulouse and went on a long tour through the Pyrenees to Bayonne, and eventually back to Montpellier, where they settled for the winter. On the trip everybody did mountain trekking and climbing, sometimes with the help of guides, and collected specimens of plants and insects. Clearly, while touring, Mill could not do much reading or studying, but his Journal, from this point written in French, illustrates his increasing mastery of the language. Even on this expedition, Mary Bentham

\footnotetext{
${ }^{31}$ Entry for 7 July 1820; Ibid., p. 41.

32 Ibid., pp. 51, 52.

${ }^{33}$ See George Bentham, Autobiography, p. 10.

${ }^{34}$ CWJSM, xxvi. p. 19.

${ }^{35}$ Ibid., p. 32.

${ }^{36}$ Ibid., p. 56.
} 
maintained her role as teacher. When describing (in his Journal) the rock formations of the Pic du Midi de Bigorre as predominantly granite and shale, the latter often 'rnicace' ('micaceous'), Mill notes: ‘Mme B. m'a explique la signification de ces mots' ${ }^{37}$ on another occasion, she advised Mill to collect specimens of plants which were not common in England, and to dry and keep them ${ }^{38}$ and at Méze, near Montpellier, he wrote a description of a distillery in the town 'suivant les explications quie Mme B a eu la bonté de me donner'. 39

While Mill was staying with the Benthams, in addition to the long trip made in the late summer, the family underwent a number of upheavals which interrupted everybody's routines. Some of these disruptions were trivial: for example, the lack of clean laundry - although with the typical disregard of the young for such matters, George had on one occasion been riding 'without saddle or stirrup ... to the no small detriment in respect to colour and to cleanness of his white pantaloons'. ${ }^{40}$ Other events were more momentous: the birth of Mary Louisa's child, and moving house with all the attendant packing up of books and other belongings. Indeed Packe interprets events thus: 'the Benthams from the outset seemed to have determined deliberately to interrupt John's reading, using the confusion consequent upon their move as a means to that end'. ${ }^{41}$ Yet in spite of a certain amount of disorder, Mill perceived that Mary Bentham was the 'ruling spirit of the household', and he describes her as 'a woman of strong will and decided character, much general knowledge, and great practical good sense'. Incidentally, the words chosen by Mill to describe Mary Bentham, 'great practical good sense', contrast starkly with his description of his own mother, as lacking 'strong good sense'. ${ }^{42}$ Filipiuk considers that 'Lady Bentham was, without doubt, a contributing factor to Mill's views about the capability of women'. ${ }^{43} \mathrm{He}$ was anxious to gain and to keep her approval, and that of the rest of the family. As he wrote to his father: 'I am very glad that Lady B has written a good account of me, as from the very first day of my arrival it has been my most earnest endeavour to please not only her, but the whole family; and nothing can give me pleasure more sincere than to learn that I have in part succeeded'. Mill seems to appreciate the

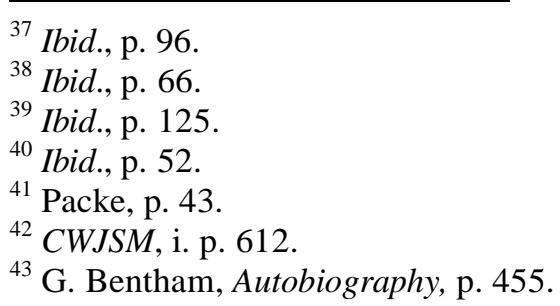


advice and help which the family gave him, saying:

the whole family, without ill humour, constantly, if I do anything amiss, tell me of it immediately, and explain to me in all respects how I ought to act. I have received from them many cautions and directions, without which I should stand some chance of meeting with a reception not very good in France... ${ }^{4}$

Perhaps the family were trying to smooth over some of the 'rough edges' of the young Mill's manner. George Bentham recollected many years later, when describing his first meeting with Mill, then aged six, that James Mill 'took the greatest pains in developping John's mind without caring for his manners', and that the boy had 'extraordinary precocity of mind with neglect of social education'. ${ }^{45}$ That John's manners were still a little unpolished at the time of his stay in France is evident from George Bentham's description of him at that time as having 'a somewhat ungainly manner which only left him late in life' ${ }^{46}$

Mill's visit to France was originally intended to last for six months. However, when the family returned from their trip and settled in Montpellier in the autumn of 1820, Lady Bentham wrote to James Mill suggesting that his son should stay with them for the winter and attend classes at the local university, this partly at the suggestion of a professor of science who had seen something of the boy's exceptional talents. ${ }^{47}$ With reference to the 'social' aspect of the education John has been receiving from the family she says:

we have been considerably successful in getting the better of his inactivity of mind and body when left to himself - Upon all occasions his gentleness under reproof, and thankfulness for correction are remarkable; and as it is by reason supported by examples we point out to him that we endeavour to convince him not by command that we induce him to act so or so, we trust that you will have satisfaction from that part of his education we are giving

\footnotetext{
${ }^{44}$ CWJSM, xxvi. p. 44.

${ }^{45}$ Autobiography, p. 9.

${ }^{46}$ Ibid., p. 63.

${ }^{47}$ In this letter she refers back to 'an account' she had sent 'of John's progress in the French language, and in other branches of study and acquirements'.
} 
him to fit him for commerce with the world at large. ${ }^{48}$

Mary Bentham's emphasis on 'reason supported by examples' in preference to 'command' as a paedogogical approach once again demonstrates her seemingly natural aptitude for the role as instructor of the young.

Thus I hope I have shown that Mary Bentham, as the 'guiding spirit' of Samuel Bentham's household, played a key part, in Mill's academic studies during his time in France, in his pursuit of extra-curricular activities, and also in the more social aspect of his development. I had long been of the opinion that her influence on Mill during that year had been significant, and a recentlydiscovered letter, dated 7 September 1820, from James Mill to Mary Bentham seems to corroborate that view. ${ }^{49}$ He writes:

From what you have stated I can have no doubt of its being a matter of first rate importance to John to remain in your society, \& under your tuition for a few months longer. There is not one of the circumstances which you point out as of importance to him, with respect to which I do not most fully concur in your sentiments.

The letter suggests that James Mill was aware of the drawbacks of his own educational methods, as he refers to 'the want of attention to ordinary objects' as 'the grand defect of [John's] previous education', and acknowledges that his son's 'exclusive attention to books has blunted the quickness of his attention to other things'. After expressing his desire that John should not become any sort of a burden to the Bentham family, James Mill continues:

I cannot express my own wishes more exactly with respect to the points to which he should give his attention, than they are expressed by your Ladyship, nor can conceive a society in which he is more likely to profit than that of your family.

It seems to me that such a tribute, from the father described as 'proud as Lucifer" 50

\footnotetext{
${ }^{48}$ Journals and Debating Speeches (CWJSM), pp. 682-83.

${ }^{49}$ Camellia plc, F. 4001.

${ }^{50}$ Correspondence $(\mathrm{CW})$, ix. 394.
} 
and as 'a cold Scotchman with more ability than principle' - the father who had '[developped] John's mind without caring for his manners' ${ }^{51}$ - such a tribute to Mary Bentham's more rounded, or as the modern term would be more 'holistic', approach to education, was high praise indeed, and surely grounds enough for this one particular woman to join the ranks of the remarkable, able and active men who influenced the young John Stuart Mill.

\section{(c) (i) ()요 \\ BY NC ND}

This work is licensed under the Creative Commons Attribution-NonCommercial-NoDerivs 2.0 UK: England \& Wales License. Under the terms of this licence, you are allowed to copy and distribute this work, but must give the original author credit. You not use this work for commercial purposes, nor alter or transform this work, without prior permission from the author. To view a full copy of this licence, visit: http://creativecommons.org/licenses/by-ncnd/2.0/uk/ or send a letter to Creative Commons, 444 Castro Street, Suite 900, Mountain View.

\footnotetext{
${ }^{51}$ G. Bentham, Autobiography, p. 9.
} 